\title{
Occurrence of fluoride in the drinking waters of Langtang area, north central Nigeria
}

\author{
H. U. Dibal ${ }^{1^{*}}$, K. Schoeneich ${ }^{2}$, I. Garba ${ }^{3}$, U. A. Lar ${ }^{1}$, E. A. Bala \\ ${ }^{1}$ Department of Geology and Mining, University of Jos, Jos, Nigeria; \\ *Corresponding Author: dibalu@unijos.edu.ng \\ ${ }^{2}$ Department of Geology, Ahmadu Bello University, Zaria, Nigeria \\ ${ }^{3}$ Kano State University of Science and Technology Wudil, Kano, Nigeria
}

Received 19 August 2012; revised 26 September 2012; accepted 8 October 2012

\section{ABSTRACT}

The aim of the study is to assess the occurrence of fluoride in the drinking water sources of Langtang area. Out of the thirty seven water samples collected from drinking water sources (hand dug wells, boreholes, streams and a spring) and analysed. Results revealed that except for fluoride, all other parameters are within the World Health Organisation recommended limits for water consumption. Fluoride in the waters ranges from $0.12-10.30 \mathrm{mg} / \mathrm{l}$ with a mean of $2.42 \mathrm{mg} / \mathrm{l}$. low levels of fluoride are recorded in the stream samples. However, no clear variations in fluoride content have been observed in both the borehole samples and those from the hand dug wells. Negative correlation exhibited between fluoride and sulphate, fluoride and Phosphate and the poor correlation between fluoride and nitrate, fluoride and chloride rules out the possibility of anthropogenic source of the fluoride in the waters. Positive correlation between lithium and magnesium, and poor but positive correlation between fluoride and lithium indicate that micas within the host rock and the pegmatite may be responsible for leaching fluoride into the waters. Two of the major water types; $\mathrm{Ca}+\mathrm{Mg}-\mathrm{HCO}_{3}$ and the $\mathrm{Na}+\mathrm{K}-\mathrm{HCO}_{3}$ water type obtain in the area have good association with fluoride content. Consumption of high fluoride waters clearly manifests in the inhabitant of the area in form of dental fluorosis and bowing of legs especially in children between the ages 7 - 11 years.

Keywords: Anthropogenic; Bowing of legs; Dental fluorosis; Fluoride; Langtang

\section{INTRODUCTION}

Fluorine often occurs in combine form in minerals as fluoride. It is highly reactive and represent about $0.06 \%$ to $0.09 \%$ of the earth crust [WHO, 1994]. Fluorine presence in groundwater is mainly a natural phenomenon, influenced mainly by local and regional geology. The main source of fluorine in groundwater is basically from mafic minerals which are concentrated in rocks. Robinson and Edington in 1964 reported the main sources of fluoride in ordinary soil consist of clay minerals. Fluoride rich minerals which are present in rocks and soils, when in contact with water of high alkalinity are released into groundwater by hydrolysis.

The effect of fluoride could either be beneficial or harmful. Hussain et al. in 2004 summarise both the beneficial and harmful effects of fluoride to be: prevention of dental caries and anti-carcinogenic agent; harmful effects to be dental fluorosis, cardiovascular disorder, gastro-intestinal disorder, endocrine effects, neurological, reproductive effects, developmental inhibition, genetic damges and effects on the pineal gland. The most common symptoms of fluoride effects is dental fluorosis, a condition involving interaction of fluoride with tooth enamel, which involves staining or blackening, weakening and possible eventual loss of teeth. With high exposure to fluoride, skeletal fluorosis can result. This manifest in the earliest stages of osteoclerosis which involves hardening and calcifying of bones and causing pain, stiffness and irregular bone growth. At its worst, the condition can result in severe bone deformation.

Dental flourosis is a common manifestation in the inhabitants of Langtang area among adults, youth and children. This has inspired the authors to determine the occurrence of fluoride in the drinikng water sources of Langtang area.

\section{THE STUDY AREA}

The study area is defined by Latitudes $9^{\circ} 00^{\prime \prime}$ and $9^{\circ} 11 " \mathrm{~N}$ and Longitudes $9^{\circ} 45^{\prime \prime}$ and $9^{\circ} 54 " \mathrm{E}$. It is part of the Crystalline Hydrogeological Province of Nigeria (Figure 1). Over $60 \%$ of the area is entirely underlain by coarse 


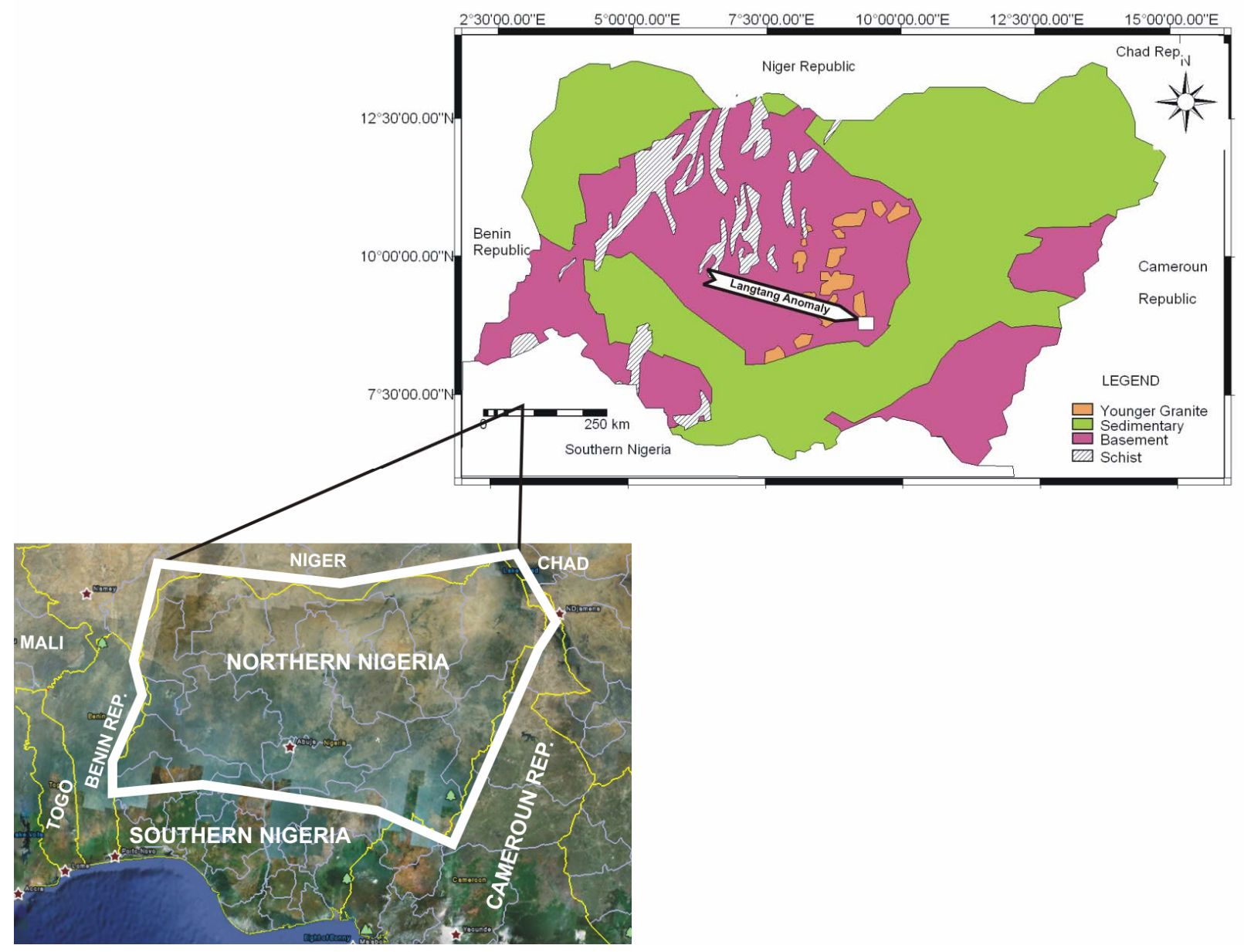

Figure 1. Location of Langtang area.

to porphyritic granite intruded by syenites on the western part, fine grained biotite granites and small scale intrusions of aplitic-, pegmatitic- and microgranites with xenoliths of the coarse to porphyritic granite a common sight (Figure 2). Small volcanic rocks are also common. The southern portion of the map is underlain by migmatites with intrusions of non orogenic granite, which probably belong to the Younger Granite series of Nigeria. Pegmatitic dykes have also intruded the migmatites. A large scale fault was formed as a result of the syenite intrusion trending in an almost N-S direction. The study area is drained by the River Bapkwai which takes its course from the hills on the western side and flow towards the south east direction. Several other small streams drain the area which flow in the same direction.

Hydrogeologically, groundwater is found in three different aquifers; recently deposited alluvium found along river and stream channels, Weathered Overburden (Soft Overburden Aquifer) and Fractured Crystalline Aquifer. Groundwater is encountered in the alluvium at depths of between 4 - 5 meters, 10 - 15 meters in the Weathered Overburden Aquifer and between 30 - 35 meters in the
Fractured Crystalline Aquifer. In the dry season, most of the hand dug wells dry up and water is obtained from scooped water holes in streams and river sands.

\section{METHODOLOGY}

\subsection{Field Sampling}

Hand dug well samples were collected with a clean plastic bucket as recommended by Davies, 1994 [1]. Samples from boreholes were pumped for several minutes with the view that stagnating water within pipe is pumped out in order to sample those coming from the formation. Spring samples were collected close to emission points to minimize contact with the atmosphere. Field parameters (temperature, $\mathrm{pH}$ ) were measured right in the field with an Oakton $\mathrm{pH} / \mathrm{MV}$ meter. Water samples were filtered with UNICEF standard filter to free them from suspended particles. Two samples were collected at each point. One was acidified with two drops of concentrated nitric acid to a $\mathrm{pH}$ of 2.0. Samples were kept in a field cooler throughout the period of the sampling exercise. 


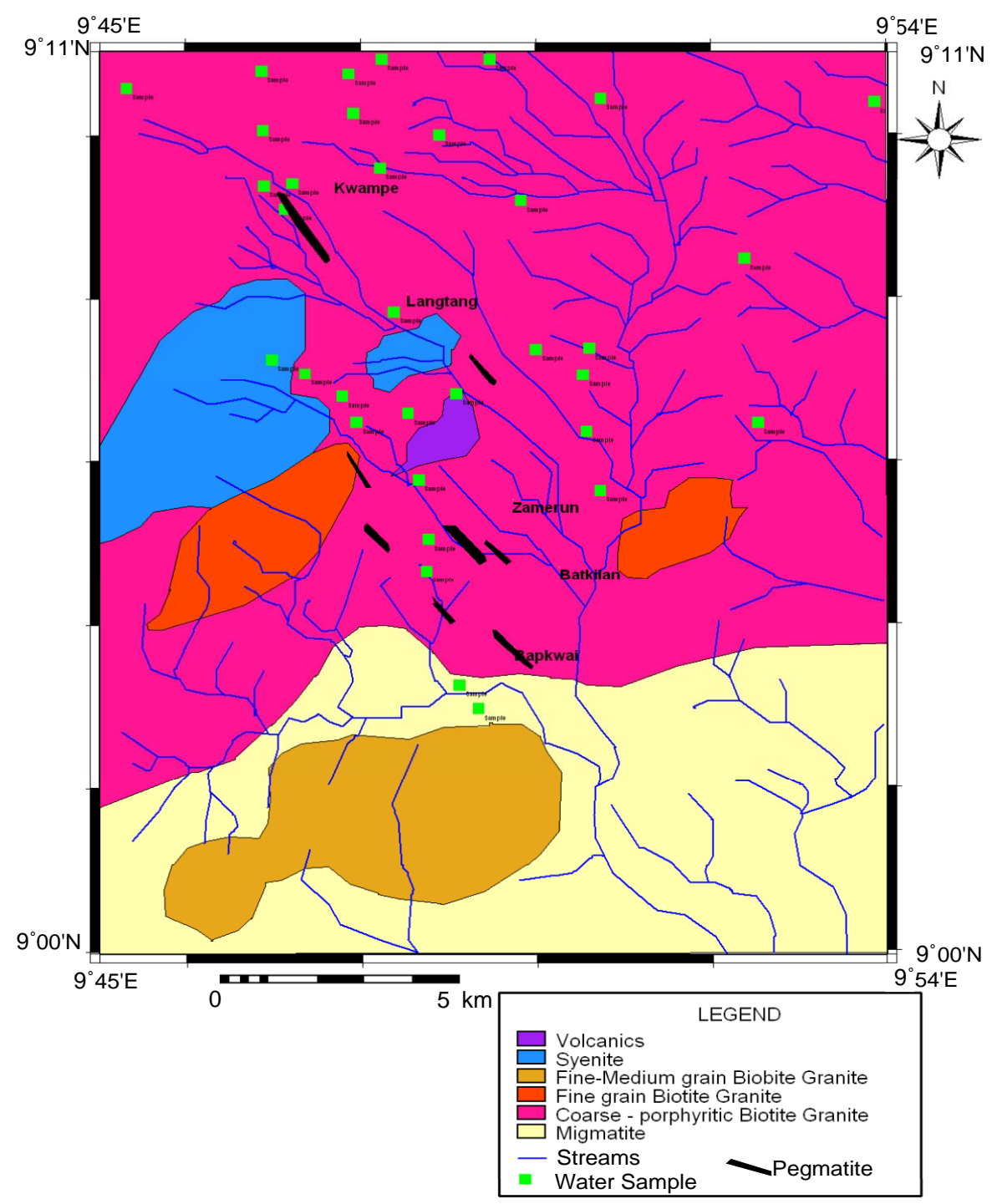

Figure 2. Geological map of Langtang area showing water sampled point [2].

\subsection{Laboratory Analysis}

Major cations and some trace elements were analysed using the Inductively Coupled Plasma Optimal Emission Spectrometry (ICPOES model 3000 ICP) at the Department of Geology and Mining, University of Jos. The composition of the anions $\left(\mathrm{Cl}^{-}, \mathrm{SO}_{4}^{=}, \mathrm{NO}_{3}^{-}, \mathrm{PO}_{4}^{=}\right)$were determined using the Ion Chromatography and Fluoride by Ion Selective Electrode (ISE) at the ACME Laboratory Vancouver, Canada. Bicarbonate alkalinity was determined by titration. Total Dissolved Solids and Total Hardness were modeled with the AqQA software.

\subsection{Statistical Analysis}

The data were statistically treated with the SPSS version 10 for windows to evaluate relationship among variables and behaviours of the elements in the hydro- geological environment. The descriptive statistical method was employed to calculate mean, minimum and maximum values of the data, while bivariate pearson moment correlation was employed to look at the relationship among the parameters.

\section{RESULTS AND DISCUSSION}

\subsection{Physico-Chemical Composition of the Waters in Langtang Area}

Table 1 shows the physical and chemical composition of the waters of Langtang area. Table 2 shows the mean, minimum and maximum values of the parameters. Temperature of the waters ranges from $26^{\circ} \mathrm{C}-27.90^{\circ} \mathrm{C}$ with a mean of $27.90^{\circ} \mathrm{C}$ as against the $26.5^{\circ} \mathrm{C}$ obtained in Crystalline Hydrogeological Province of Nigeria as given by Schoeneich and Garba, 2010 [3]. Hydrogen exponent 


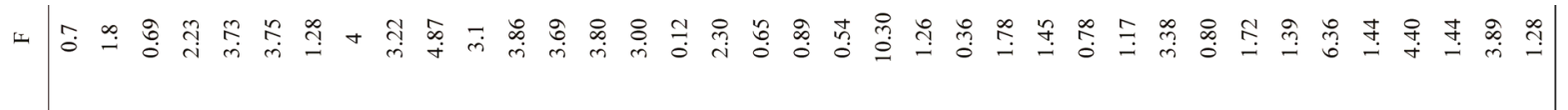

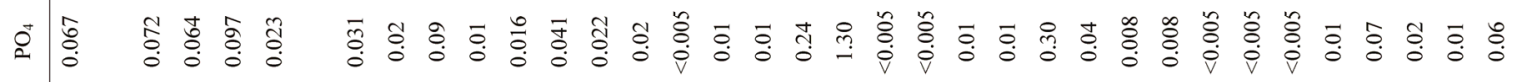

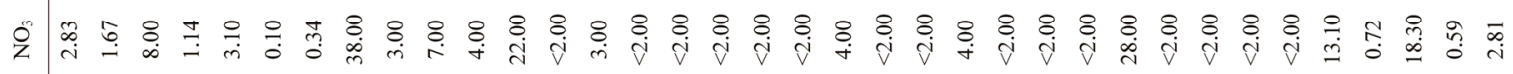

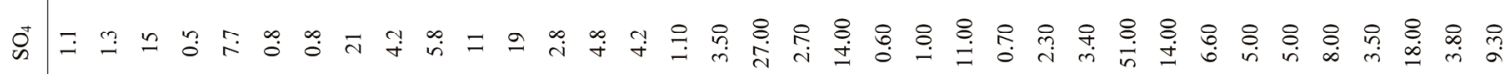
U

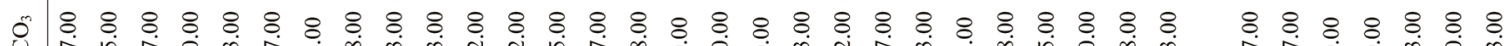

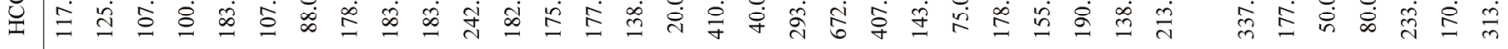

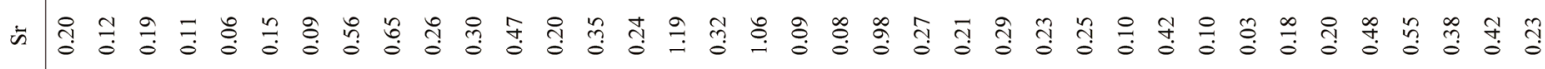
= ఇ

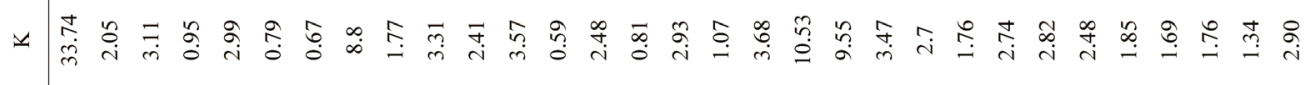

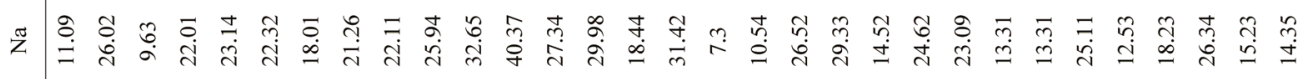

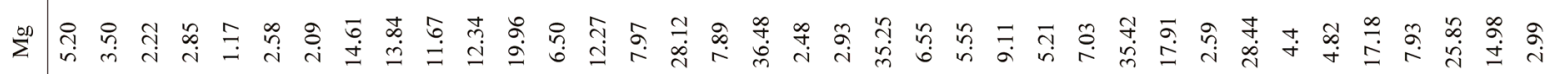

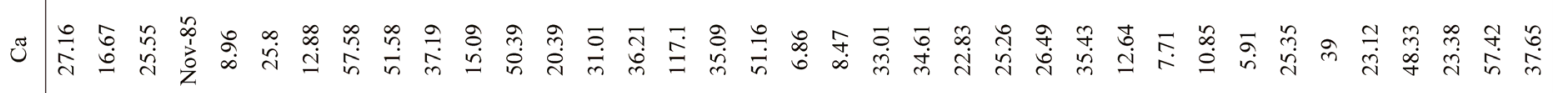

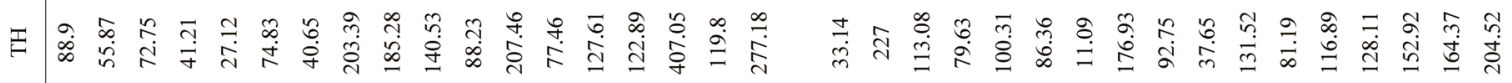

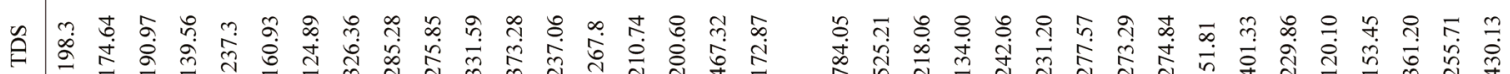

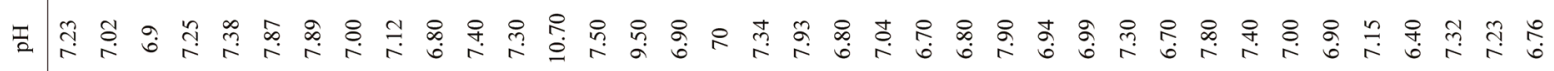

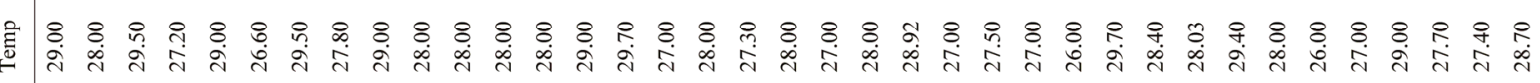

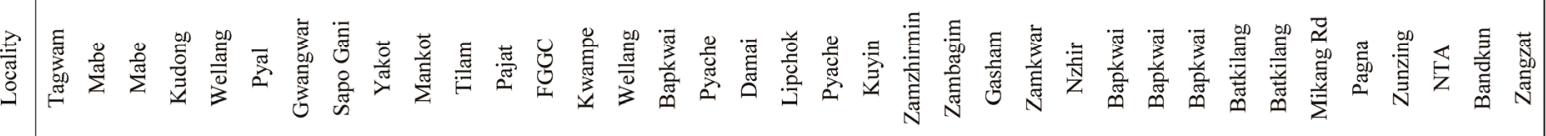

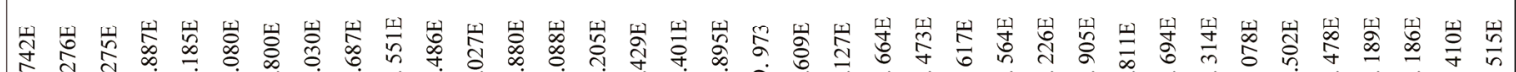

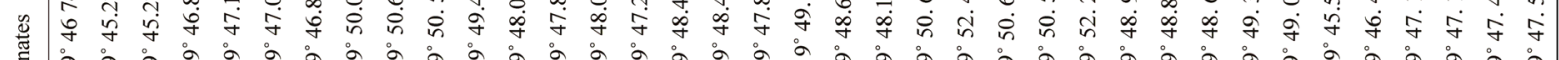

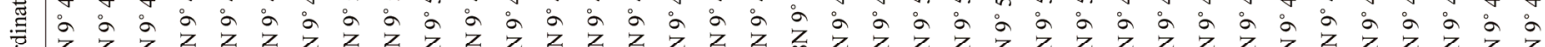

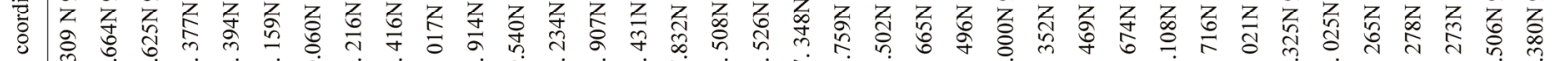

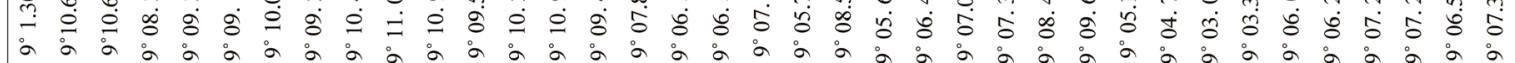

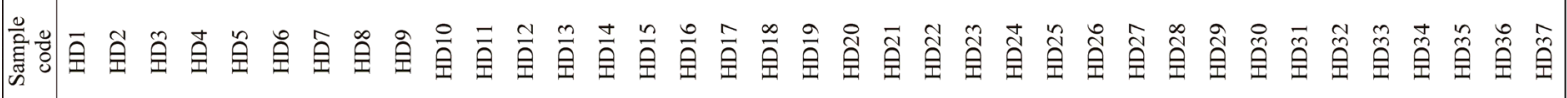


Table 2. Minimum, maximum and mean values of physical and chemical parameters in langtang area.

\begin{tabular}{|c|c|c|c|c|c|c|}
\hline Parameters & No & Minimum & Maximum & Mean & $\begin{array}{l}\text { Crystalline Hydrogeological } \\
\text { Province Average }\end{array}$ & $\begin{array}{l}\text { WHO Standards, } \\
2004\end{array}$ \\
\hline Temperature & 41 & 26.00 & 27.90 & 27.90 & $26.5^{\circ} \mathrm{C}$ & - \\
\hline $\mathrm{pH}$ & 41 & 6.40 & 10.70 & 7.32 & $5.0-7.4$ & $6.5-8.5$ \\
\hline TDS & 36 & 51.81 & 784.05 & 268.27 & $60 \mathrm{mg} / \mathrm{l}$ & 500 \\
\hline $\mathrm{TH}$ & 36 & 11.09 & 407.06 & 120.11 & 20 mg/l & 500 \\
\hline $\mathrm{Ca}$ & 41 & 5.91 & 117.10 & 30.31 & $3.0 \mathrm{mg} / \mathrm{l}$ & 75 \\
\hline Mg & 41 & 1.17 & 36.48 & 11.16 & $1.1 \mathrm{mg} / \mathrm{l}$ & 150 \\
\hline $\mathrm{Na}$ & 41 & 5.07 & 40.37 & 19.98 & $5.0 \mathrm{mg} / \mathrm{l}$ & 200 \\
\hline K & 41 & 0.59 & 33.74 & 4.00 & $1.5 \mathrm{mg} / \mathrm{l}$ & - \\
\hline $\mathrm{HCO}_{3}$ & 35 & 20.00 & 672.00 & 187.97 & $30 \mathrm{mg} / \mathrm{l}$ & - \\
\hline $\mathrm{Cl}$ & 36 & 0.50 & 75.00 & 11.59 & $0.6 \mathrm{mg} / \mathrm{l}$ & 500 \\
\hline $\mathrm{SO}_{4}$ & 36 & 0.50 & 51.00 & 8.10 & $1.3 \mathrm{mg} / \mathrm{l}$ & 400 \\
\hline $\mathrm{F}$ & 37 & 0.12 & 10.30 & 2.47 & $0.3 \mathrm{mg} / \mathrm{l}$ & 1.5 \\
\hline
\end{tabular}

(pH) ranges from 6.40 - 10.70 with a mean of 7.32 , indicating waters in the study area to be slightly acidic to mildly alkaline. Total Dissolve Solids ranges from 51.81 784.05 with a mean of 268.27. Reasons for this high values cannot easily be explained, but probably it may be the result of residential pollution. Total Hardness ranges from 11.09 - 407.06 with a mean 120.11. According to Davies and Deweist 1966, classification of water hardness, $22 \%$ of the waters are classified as soft, $61 \%$ as moderately hard and the remaining $17 \%$ as hard. Calcium ranges from 5.91 - $117.10 \mathrm{mg} / \mathrm{l}$ with a mean of $30.31 \mathrm{mg} / \mathrm{l}$. This mean value is ten times more than the mean of $3.0 \mathrm{mg} / \mathrm{l}$ given by Schoeneich and Garba, 2010 [3] for calcium in Crystalline Hydrogeological Province of Nigeria. Dissolution of calcium bearing mineral alone cannot account for this high concentration of calcium in the Langtang waters. Magnesium ranges from 1.17 $36.48 \mathrm{mg} / \mathrm{l}$ with a mean of $11.16 \mathrm{mg} / \mathrm{l}$, Sodium ranges from 5.07 - 40.37 with a mean of $19.98 \mathrm{mg} / \mathrm{l}$. Potassium ranges from 0.59 - 33.74 with a mean of $4.00 \mathrm{mg} / \mathrm{l}$. These values are all higher than those given by Schoeneich and Garba, 2010 [3] for waters in the Crystalline Hydrogeological Province of Nigeria. Bicaarbonate in the waters ranges from $20.00-672.00 \mathrm{mg} / \mathrm{l}$ with a mean of $187.97 \mathrm{mg} / \mathrm{l}$, sulphate ranges from 0.50 - 51.00 with a mean of $8.10 \mathrm{mg} / \mathrm{l}$. A borehole at Bapkwai has this value of $51.00 \mathrm{mg} / \mathrm{l}$. Chloride ranges from 0.50 $75.00 \mathrm{mg} / \mathrm{l}$ with a mean of 11.90 . Few of the water sources have elevated levels of sulphate with corresponding elevated levels of nitrate. Such water sources may have been polluted.

\subsection{Correlation Coefficient between Fluoride and Other Parameters in Langtang}

Correlation coefficient between fluoride and some parameters in Langtang area is shown in Table 3. Very poor correlation is exhibited between temperature, $\mathrm{pH}$ and all other parameters indicating little influence of $\mathrm{pH}$ and temperature on the presence of these parameters in the waters. However, positive correlation between $\mathrm{pH}$ and Fluoride has been established by Handa, 1975 [4]; Edmunds, 1994 [5], Gaciri and Davies, 1994 [6]; Rao, 2002; Fordyce et al., 2007 [7]. Positive correlation between TDS and bicarbonate, phosphate and chloride indicates contribution of these ions to salinization of groundwater in the area. Positive correlation between total hardness and calcium, magnesium, barium, and strontium with correlation coefficient values; 0.748, $0.744,0.474$ and 0.805 indicate the contribution of these ions to hardness of water in the study area. Positive correlation between calcium and barium and strontium shows that these ions may be from the same source, probably feldspars. The positive correlation exhibited between magnesium and lithium and that between fluoride and lithium at the 0.05 significant levels shows that these ions are from the same source, probably micas. Fluoride correlates negatively with sulphate and phosphate and poorly correlates with chloride and nitrate. This probably indicate that, the source of fluoride in the 
waters may not to be from anthropogenic sources, confirming the very low and near absence of nitrate in over $70 \%$ of the water sources.

\subsection{Fluoride Concentration and Groundwater Types in Langtang Area}

Classification of groundwater type for the area was adopted after Back and Hanshaw, 1965 [8] (Figure 3). $\mathrm{Ca}+\mathrm{Mg}-\mathrm{HCO}_{3}$ water type constitute $70 \%$ of the water types, with fluoride concentration ranging from 0.12 $10.30 \mathrm{mg} / \mathrm{l}$. The $\mathrm{Na}+\mathrm{K}-\mathrm{HCO}_{3}$ water type constitutes $23 \%$ with fluoride concentration ranging from 0.54 $3.74 \mathrm{mg} / \mathrm{l}$ and the $\mathrm{Na}+\mathrm{K}_{-} \mathrm{SO}_{4}+\mathrm{Cl}$ constituting $7 \%$ with fluoride concentration of $0.65 \mathrm{mg} / \mathrm{l}$. The $\mathrm{Na}+\mathrm{K}-\mathrm{SO}_{4}+$ $\mathrm{Cl}$ water type in the area may be contribution from anthropogenic sources and or minerals rich in sulphate and chloride. The $\mathrm{Ca}+\mathrm{Mg}-\mathrm{HCO}_{3}$ water types reflect compositions of waters of meteoric origin. $\mathrm{Na}+\mathrm{K}-\mathrm{HCO}_{3}$ water type, may be the result of base exchange between calcium for sodium as proved by Bond 1946 [9], Foster, 1950 [10] and Boyle 1992 [11]. Studies on rich fluoride groundwater to be of the $\mathrm{Na}+\mathrm{K}-\mathrm{HCO}_{3}$ water type have been established by Gaciri and Davies, 1993 [6]; Handa, 1975 [4]; Gupta et al., 1986 [12]; Edmunds, 1994 [5].

\subsection{Distribution of Fluoride in Langtang Waters}

Fluoride distribution image map of langtang area is shown in Figure 4. The intervals used for mapping fluoride concentrations are based on expected dose-response health outcomes given by the World Health Organisation. Fluoride concentration higher than the World Health Ogarnisation upper limit of $1.5 \mathrm{mg} / \mathrm{l}$ and $1.0 \mathrm{mg} / \mathrm{l}$ proposed background value [2] are found in the northeastern portion of the map and towards the southwestern portion (Figure 4). Fluoride concentration lower than these values, are found occupying a small portion in the northwest and a larger portion to the south. No clear variation of fluoride concentration is seen in the different sources from which water was collected (Table 1). Waters collected from scooped sands along stream channels (Plate 1) have lower fluoride concentration as against those in hand dug wells and boreholes. Probably this is because waters in the streams are recently infiltrated water from immediate past rainfall and therefore did not have enough time to interact with fluorine bearing minerals. Boreholes and hand dug wells have similar levels of fluoride, indicating that depths of water sources in the

\section{Piper Diagram}

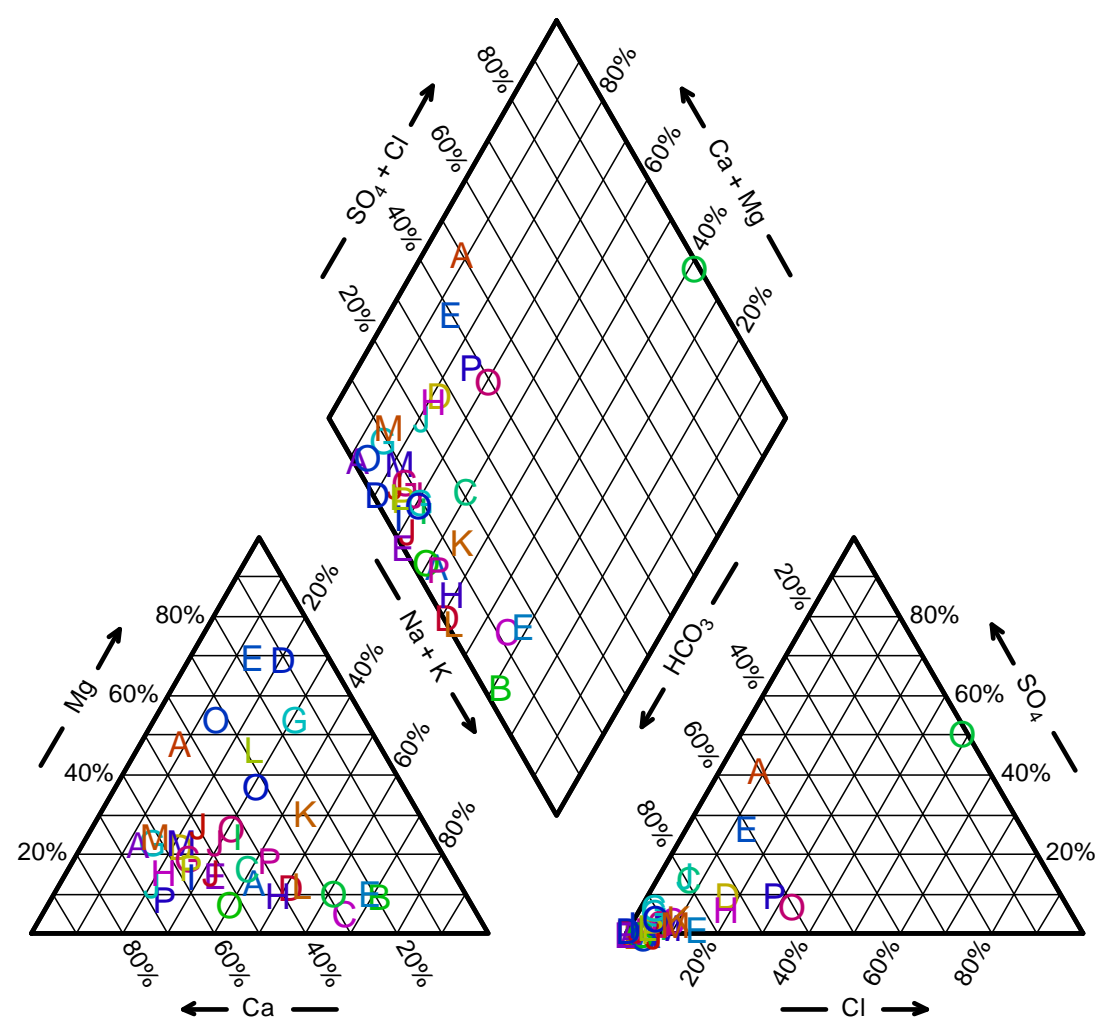

\begin{tabular}{||ll||}
\hline & Legend \\
A & HD1 \\
D & HD2 \\
P & HD3 \\
L & HD4 \\
C & HD5 \\
O & HD6 \\
H & HD7 \\
D & HD8 \\
M & HD9 \\
J & HD10 \\
K & HD11 \\
O & HD12 \\
P & HD13 \\
I & HD14 \\
G & HD15 \\
G & HD16 \\
A & HD17 \\
A & HD18 \\
B & HD19 \\
E & HD20 \\
O & HD21 \\
E & HD22 \\
C & HD23 \\
J & HD24 \\
P & HD25 \\
J & HD26 \\
11 & More... \\
\hline
\end{tabular}

Figure 3. Diagram showing water types in Langtang area. 


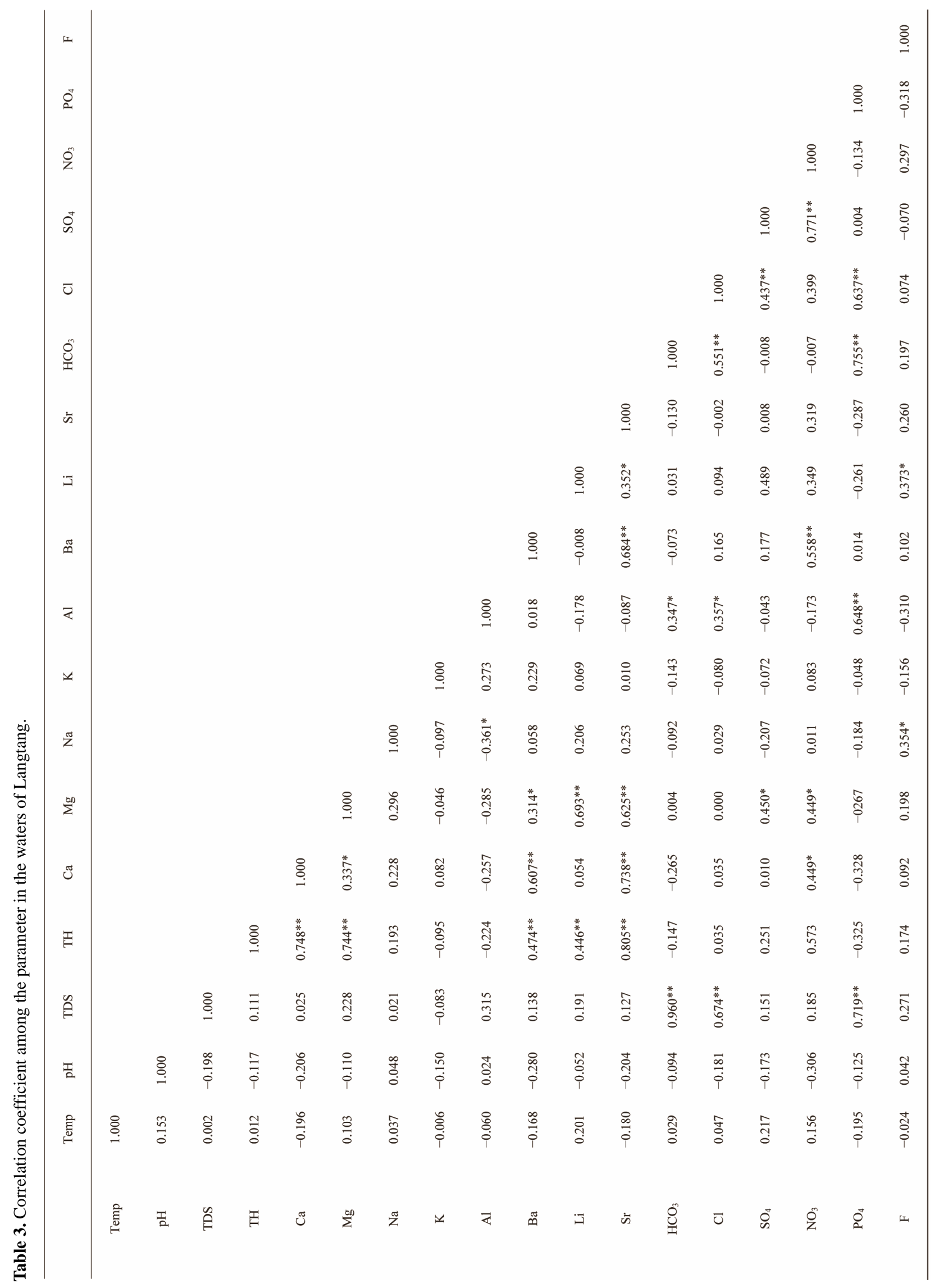




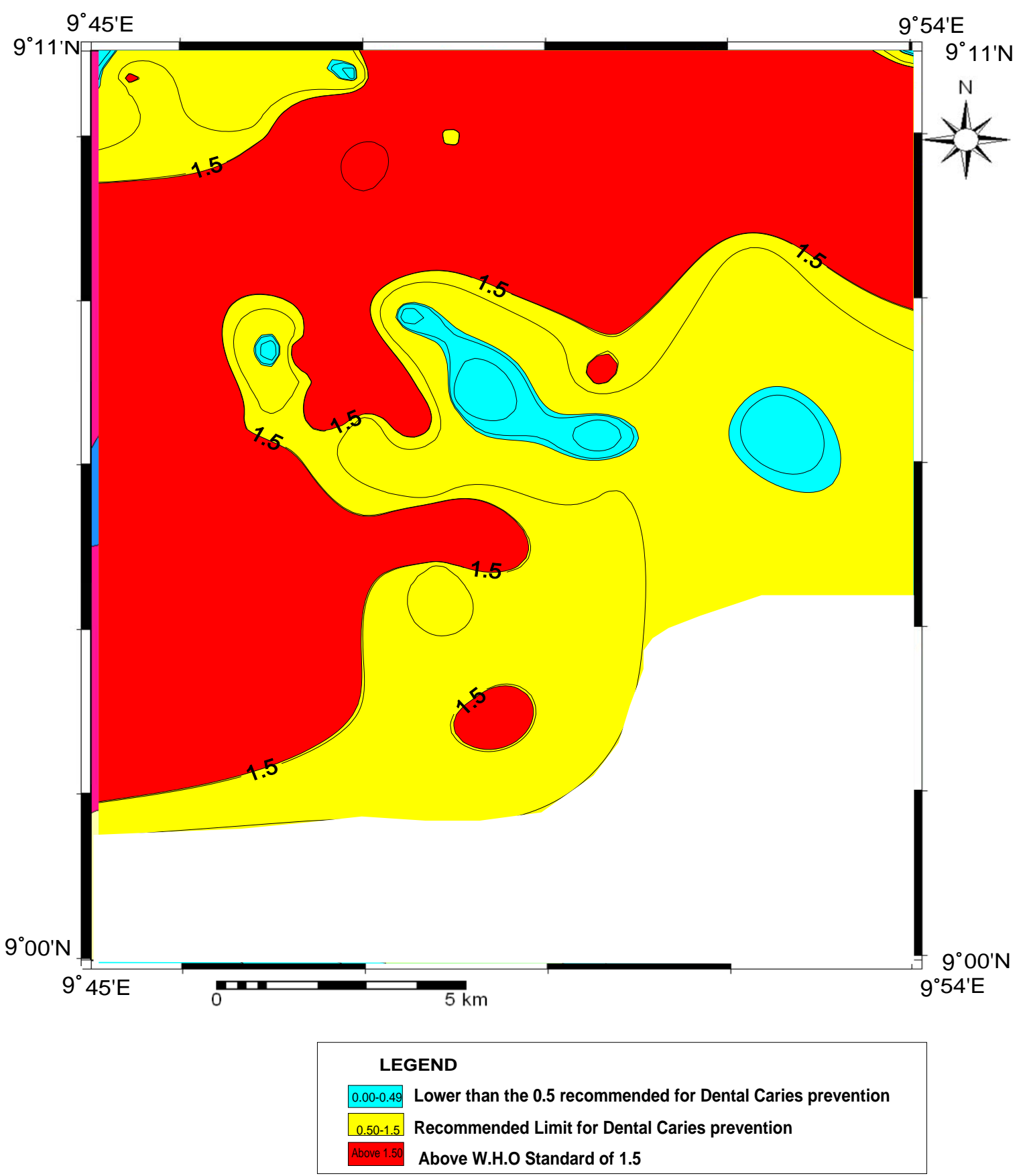

Figure 4. Fluoride distribution image map of Langtang area.

Lantang area do not determine concentration of fluoride. Boyle and Chagnon in 1995 [13] have established the increase of fluoride concentration with depth. One of the water source (hand dug well at Kuyin) located in the eastern portion of the study area has the highest level of fluoride concentration of $10.30 \mathrm{mg} / \mathrm{l}$.

\subsection{Source of Fluoride in the Waters}

Foster, 1950 [10]; Boyle, 1992 [11] said that minerals whose composition influences the hydrogeochemistry of fluoride are fluorite, apatite, micas, amphiboles, certain clays and villaumite. However, fluorite is the main mineral controlling aqueous fluoride geochemistry in most environments; some notable exception in sedimentary environment and certain igneous rocks according to Krainove et al., 1969 [14] are apatite, micas, and amphiboles which have much lower solubilities than fluorite; the dissolution of these minerals is most pronounced at low $\mathrm{pH}$. 


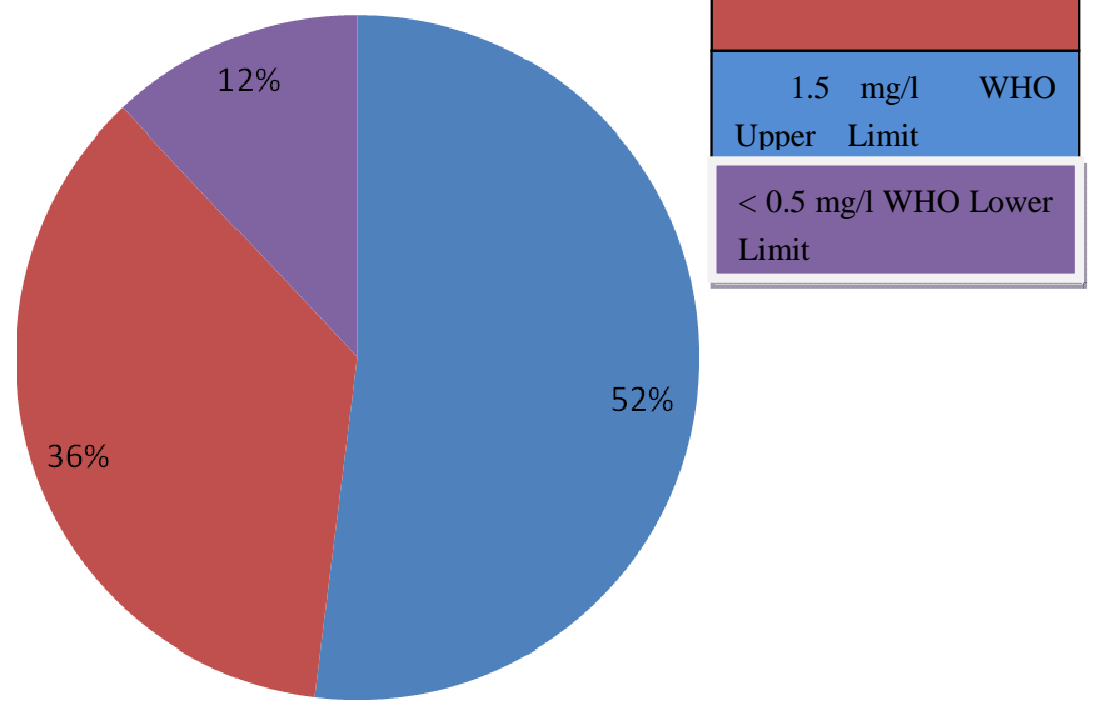

Plate 1. Pie diagram showing percentage concentration of fluoride in the waters of Langtang area compared with the WHO standard.

Negative correlation exhibited between fluoride and sulphate, fluoride and phosphate and the poor correlation between fluoride and nitrate, fluoride and chloride rules out the possibility of fluoride in the waters to be from anthropogenic sources. Fluor-apatite minerals or phosphate fertilizer as suggested by Subba Rao, 2003 [15] may not also be responsible for leaching fluoride into the waters, because of the negative correlation exhibited between fluoride and Phosphate. The positive correlation between Lithium and magnesium and between fluoride and lithium at both the 0.01 and 0.05 significant levels indicates they are from the same source, probably the micas. A study carried out by Apambire in 1997 [16] in waters of Ghana showed that lithium micas are responsible for fluoride rich groundwater. Also, Korting in 1972 [17] said that about 80 to $90 \%$ of fluorides are contained in muscovite, illite, and related minerals of the mica group. Chae et al., 2007 [18]; Li, et al., 2007 [19] and Nordstrom and Jenne, 1977 [20] have suggested likely source of fluoride in groundwater to be the weathering of biotite.

\subsection{Water Quality and Health Effect of Fluoride in Langtang Area}

Only 13 (36\%) out of the 36 water sources analysed for fluoride content waters have fluoride within the WHO 2004 optimal level of $0.5-1.5 \mathrm{mg} / \mathrm{l}$. 12\% of the water sources have fluoride concentration lower than the $0.5 \mathrm{mg} / \mathrm{l}$ lower limit recommended for dental caries prevention. Population of inhabitants consuming water from these sources may therefore be at the risk of having dental caries. 52\% of the water sources in the area have fluoride concentration greater than the $1.5 \mathrm{mg} / \mathrm{l}$ WHO upper limit.

Based on the WHO 2004 [21], classification of chronic health effects of fluoride consumption in drinking water, population consuming water from 13 of the 20 water sources with fluoride value greater than $1.5 \mathrm{mg} / \mathrm{l}$ may have dental fluorosis. Inhabitants consuming water in the remaining 7 water sources with fluoride concentration from $4.0 \mathrm{mg} / \mathrm{l}$ and upwards may have chronic skeletal fluorosis. Earlier studies carried out in the area, has established chronic manifestation of dental fluorosis in school children and youths [22,23] with greater manifestation in school children aged between 7 - 11 years. Cases of genu valgum (bowing of legs) have also been established in school children in the same age bracket by Wongdem et al. in 2002 [23].

\section{SUMMARY AND CONCLUSION}

A study carried out on the occurrence of fluoride in the drinking water sources of Langtang area show that except for fluoride all other parameter determined in the waters are within the World Health Organisation recommended for drinking water. Fluoride contents in the streams are very low as compared to those obtained in the handug wells and the boreholes. There are no clear variations observed in fluoride contents recorded in hand dug wells and boreholes. $\mathrm{pH}$ and temperatures of the waters show very poor correlation with most of the parameters determined in the area. This indicates little influence of the two parameters on the presence of the other parameters. Negative correlation exhibited between fluoride and sulphate, fluoride and phosphate and the 
very poor correlation between fluoride and chloride, fluoride and nitrate, rules out sources of fluoride in the waters to be from anthropogenic, phosphate fertilizer and apatite minerals. Positive correlation between lithium and magnesium and the positive but poor correlation between lithium and fluoride may probably be from micas in the host rock and the intrusions of pegmatite in it. Two of the water types obtained in the area all have good association with fluoride. Consumption of this high fluoride waters manifest in the inhabitants of the area in form of dental fluorosis and bowing of legs.

\section{ACKNOWLEDGEMENTS}

The authors are grateful to the reviewers for their constructive criticism which has led to the success of this paper. We are also grateful to Caleb Kushaluwong for the map work.

\section{REFERENCES}

[1] Davies, T.C. (1994) Water quality characteristics associated with fluorite mining in the Kerio Valley area of western Kenya. International Journal of Environmental Health Research, 4, 165-175. doi:10.1080/09603129409356814

[2] Dibal, H.U. (2012) Fluoride concentration in some parts of northern Nigeria. Ph.D. Dissertation, Ahmadu Bello University, Zaria.

[3] Schoeneich, K. and Garba, M.L. (2010) Hydrogeology. Lecture notes for students of geology. Ahmadu Bello University, Zaria.

[4] Handa, B.K. (1975) Geochemistry and genesis of fluoride containing ground waters in India. Groundwater, 25, 255264.

[5] Edmunds, W.M. (1994) Characterization of groundwaters in Semi-Arid and Arid Zones Using Minor Elements. In: Nash, I.I. and McCall, G.J.H., Eds., Groundwater Quality, Chapman and Hall, London, 19-30.

[6] Gaciri, S.J. and Davies, T.C. (1993) The occurrence and geochemistry of fluoride in some natural waters of Kenya. Journal of Hydrology, 143, 395-412. doi:10.1016/0022-1694(93)90201-J

[7] Fordyce, F.M., Vrana, K., Zhovinsky, E., Povoroznuk, V., Toth, G., Hope, B. C., Iljinsky, U. and Baker, J. (2007) A health risk assessment for fluoride in central Europe. Journal of Environmental Geochemistry and Health, 29, 83-102. doi:10.1007/s10653-006-9076-7

[8] Back, W. and Hanshaw, B.B. (1965) Advances in hydrosciences. In: Sadashiviah, Ed., India International Journal of Environmental Research and Public Health, 159164.

[9] Bond, D.W. (1946) A geochemical survey of the undergroundwater supplies of the Union of South Africa. In: Boyle, D.R. and Chagnon, M., Eds., An Incidence of Skeletal Florosis Associated with Groundwater of the Maritime Carboniferous Basin, Gaspe Region, Quebec, Canada. Environmental Geochemistry and Health, 17, 5-12.
[10] Foster, M.D. (1950) The origin of high sodium bicarbonate waters in the Atlantic and Gulf Coastal Plains. Geochimica Cosmochimica Acta, 1, 32-48. doi:10.1016/0016-7037(50)90007-X

[11] Boyle, D.R. (1992) Effects of base exchange softening on fluoride uptake in groundwaters of the moncton sub-basin new brunswick Canada. In: Kharaka, Y.K. and Maest, A.S., Eds., Water-Rock Interaction, 7th International Symposium on Water-Rock Interaction, Rotterdam, 771774.

[12] Gupta, S.C., Doshi, C.S and Palivval. B.L. (1986) Occurrence and chemistry of high fluoride ground water in Jalore district of western Rajasthan. Annals of Arid Zone, 25, 255.

[13] Boyle, D.R. and Chagnon, M. (1995) An incidence of skeletal florosis associated with groundwater of the maritime carboniferous basin, Gaspe Region, Quebec, Canada. Environmental Geochemistry and Health, 17, 5-12. doi:10.1007/BF00188625

[14] Krainove, S.R., Merkov, A.N., Petrova. N.G., Baturinskaya, I.V. and Zharikova, V.M. (1969) Highly alkaline (pH 12) fluosilicate waters in the deeper zone of Lovozero Massif. In: Sandow, M.Y. et al., Eds., A Factor Model to Explain the Hydrochemistry and Causes of Fluoride in Groundwater from the Middle Voltaian Sedimentary Aquifer in the Northern Region, Ghana. APRN Journal of Engineering and Applied Sciences, 7, 1-19.

[15] Subba Rao, N. (2003): Groundwater prospecting and management in an agro-based rural environment of crystalline terrain of India. Environmetal Geology, 43, 419- 431.

[16] Apambire, W.B., Boyle, D.R and Michael, F.A. (1997) Geochemistry, genesis and health implication of fluoriferous groundwater in the upper region of Ghana. Environmental Geology, 33, 13-24. doi:10.1007/s002540050221

[17] Korting, S. (1972) Flourine 9B-9O. In: Beg, M.K., Ed., Geospatial analysis of fluoride contamination in groundwater of Tamnar area, Raigarh District Cchatrtigarh State, India. Unpublished M.Sc Thesis submitted to International Institute of Geo-information Science and Earth observation.

[18] Chae, G.Y., Seong, T.M., Bernhard, K., Kyoung, K. and Seong-Yong, K. (2007) Fluoride geochemistry in bed rock groundwater of South Korea. Science of the Total Environment, 385, 272-283. doi:10.1016/j.scitotenv.2007.06.038

[19] Li, Z., Tainoshi, Y., Shirashi, K and Owada, M. (2003) Chemical characteristics of fluoride bearing biotite of Early Paleozoic plutonic rocks from the Sor Rondane Moutains, East Antartica. Journal of Geochemistry, 37, 145-161.

[20] Nordstrom, D.K. and Jenne, E.A. (1977) Fluorite solubility in selected geothermal waters. Geochima Cosmochima Acta, 41, 175-188.

[21] WHO (2004) Guidelines for drinking water quality. 3rd Edition, World Health Organization, Geneva.

[22] Dibal, H.U., Lekmang, I.C. and Lar, U.A. (2007) Dental fluorosis from drinking water consumptipon in Langtang town, Plateau State. Continental Journal of Earth Sci- 
ences, 3, 77-82.

[23] Wongdem, J.G., Aderinokun, G.A., Sridhar, M.R. and Selkur. S. (2002) Prevalence and distribution pattern of enamel fluorosis in Langtang Town. African Journal of Medical Science Fluoride, 35, 120-135. 